"This is the peer reviewed version of the following article: [Accounting and Finance 2016], which has been published in final form at [http://dx.doi.org/10.1111/acfi.12118]. This article may be used for noncommercial purposes in accordance with Wiley Terms and Conditions for Self-Archiving." 


\title{
AN INVESTIGATION OF WHOLLY OWNED FOREIGN SUBSIDIARY CONTROL THROUGH TRANSACTION COST ECONOMICS THEORY
}

\author{
Francesco Giacobbe $^{\mathrm{a}}$, Zoltan Matolcsy ${ }^{\mathrm{a}}$, James Wakefield ${ }^{\mathrm{a} *}$ \\ ${ }^{\text {a } U T S ~ B u s i n e s s ~ S c h o o l, ~ A c c o u n t i n g, ~ U n i v e r s i t y ~ o f ~ T e c h n o l o g y, ~ S y d n e y, ~ A u s t r a l i a ~}$
}

JEL classification: M41

Keywords: wholly owned foreign subsidiaries, international operations, management control systems, transaction cost economics

Acknowledgements: An earlier version of this paper received the Best Paper Award in the Management Accounting Stream at the 2012 AFAANZ conference. We would like to thank Martin Bugeja, Bruce Dehning, Dan Dhaliwal, David Erkens, Markus Granlund, Teemu Malmi, Ken Merchant, Frank Moers, Matthew Peters, Gerhard Speckbacher for their valuable comments and suggestions. We would also like to thank participants at the UTS seminar series; 2012 Global Management Accounting Symposium (GMARS); 2012 AFAANZ conference; 2013 BAFA conference; 2013 EAA conference; Monash University seminar series (2013); and the University of Southern California seminar series (2014) for their valuable comments and suggestions.

\section{*Corresponding author, James Wakefield}

UTS Business School, Accounting, University of Technology Sydney

City Campus, PO Box 123 Broadway, NSW 2007 Australia

Tel: +61 29514 3583; Email: James.Wakefield@uts.edu.au 


\title{
An investigation of wholly owned foreign subsidiary control through transaction cost economics theory
}

\begin{abstract}
This paper investigates the management control systems used by multinational corporation headquarters to control wholly owned foreign subsidiaries. Our theory development is based on transaction cost economics. First we conduct a series of exploratory interviews, providing an insight into the context, and second we provide some empirical evidence based on cross sectional survey data. Our results indicate that activity traits (uncertainty, asset specificity and post hoc information impactedness) have significant implications on control choices, in particular the control archetype combinations chosen by headquarters, although not all results are consistent with theory predictions. Our findings are supported by extensive alternative testing.
\end{abstract}




\section{Introduction}

Wholly owned foreign subsidiary (WOFS) entities have and continue to be important vehicles for firms seeking to capitalise on foreign market opportunities, particularly with the removal of foreign ownership barriers throughout the world (Colombage, Gunasekarage, and Shams 2014). However the success of such ventures is mixed (Eden and Miller 2004) and accordingly investigating a comprehensive set of control determinants and the associated control mechanisms is a fundamental step. The objective of this paper is to investigate the choice of management control systems exercised by headquarters controlling WOFS operations, broadly based on a transaction cost economics (TCE) approach proposed by Speklé (2001).

The motivation for conducting this study is twofold. First WOFS entities are an integral and economically significant part of the Australian economy. The net value of Australian companies abroad is appropriately AUD\$875 billion and this continues to expand between AUD\$20 million and AUD\$30 billion per year, with much of it relating to WOFS operations ${ }^{1}$. Hence we aim to provide some guidance to practice concerning the management control systems exercised and characteristics associated with these choices. Our second motivation is that much of the research in this area frequently considers only a narrow set of control choices (Bourmistrov and Kaarbøe 2013; Dossi and Patelli 2008). It is surprising there is not more comprehensive consideration of controlling WOFS, particularly concerning research in the Asia Pacific region (Chenhall and Smith 2011; Benson et al. Forthcoming; Benson, Faff, and Smith 2014), given the importance of these entities for multinational corporations and control problems faced (Mason 2007). Accordingly we aim to develop a more comprehensive approach by drawing from Speklé's (2001) TCE theory of management control as a starting point in this study.

\footnotetext{
${ }^{1}$ See Australian Bureau of Statistics, Australia Economic Indicators, September 2014.
} 
The WOFS context is characterised by some unique factors, aligning with TCE theory. These include internal networks, external networks and strategic choices which are critical to the viability of WOFS operations given the knowledge acquisition they facilitate (Forsgren, Pedersen, and Foss 1999; Tallman and Fladmoe-Lindquist 2002). These network and strategic factors lead to a variation in knowledge at different organisational levels, a key driver of headquarters degree of uncertainty concerning WOFS operations (Williamson, 1979). Further, networks developed and strategic choices are related to the asset specificity of WOFS operations and post hoc information impactedness from headquarters' perspective (Williamson, 1979). Therefore WOFS operations can be characterised according to the link between activity traits (uncertainty, asset specificity and post hoc information impactedness) described in transaction cost economics (TCE) theory and the problems headquarters face, which can be addressed through management control systems. A number of studies assert the relevance of TCE theory to aid in the explanation of control choices, including Spicer and Ballew (1983), Bogaard and Speklé (2003).

We start by conducting a series of exploratory interviews to gain an insight into the applicability of TCE theory and modify Speklé's (2001) conceptualisation consistent with the control choices and associations with activity traits observed in the WOFS context. These insights inform the development of a survey we conduct, so it is meaningful in the context examined (Abernethy et al. 1999). Survey data is collected from 159 firms to more comprehensively examine the control of WOFS operations. Our findings indicate that headquarters do not choose a single set of control choices, as proposed by Speklé (2001), rather they choose combinations of the sets of control proposed. These sets of control choices are associated to a certain extent with the activity traits observed. 
This study contributes to literature in a number of ways. First, literature concerning the control of foreign subsidiaries rarely distinguishes between wholly owned operations and joint venture operations (Jaussaud and Schaaper 2006). Generalising the implications of findings from this literature is problematic, given headquarters controlling joint ventures are faced with unique issues associated with sharing control, bargaining power and competing partner interests (Chalos and O'Connor 2004; Emsley and Kison 2007). Headquarters controlling WOFS operations need to deal with and control foreign operations alone, in sometimes unfamiliar markets. Second, literature often deals with one or a limited number of control mechanisms in each study (such as performance measurement systems), rather than more comprehensive sets of control mechanisms or control packages (Sandelin 2008; Malmi and Brown 2008). Through examining this unique context and broader set of control choices within it, we contribute to developing a more comprehensive understanding of that is relevant to both theory development and practice (Merchant 2012).

The next section explains the implications of TCE and Speklé's (2001) theory which we refer to when examining this context. The suggestions, from a series of exploratory interviews, then provide insight into TCE applicability in this context. The analysis of the survey data is then presented, following by the findings and conclusion.

\section{Theory development}

\subsection{Control problems facing headquarters and transaction cost economics}

The problems headquarters face when controlling WOFS operations at a distance are captured through the activity traits described in TCE theory (Williamson 1979, 2005). In this study activity traits are essentially descriptors of a WOFS (domain of transactions) from the perspective of headquarters. Activity traits in the presence of human traits, bounded 
rationality and opportunism, are argued to lead to control problems. This section defines and describes these activity traits and associated human traits in the context of WOFS operations.

Uncertainty refers to the specificity of intended performance and activities of WOFS operations (ex ante) and is associated with the predictability of the WOFS context (environment). Behavioural uncertainty is very relevant, in this context, based on headquarters' familiarly with subsidiary practices and processes associated with foreign markets, particularly concerning government regulations, local customs, business networks and market developments (Rindfleisch and Heide 1997). Unfamiliarity arises in many cases due to the distance between headquarters and WOFS operations (Moilanen 2007). Bounded rationality, referring to limited cognitive and computational ability to arrive at decisions (Simon 1945), is problematic where uncertainty is high due to the limits on headquarters ability to effectively provide direction at a distance (Williamson 1979, 2005).

Distinct control problems occur when uncertainty is combined with a second activity trait, asset specificity. Asset specificity refers to the extent it is possible to redeploy asset to an alternative activity, with larger opportunity costs associated with higher specificity (Williamson 1979). Opportunity costs may be further increased in this context due to limits on headquarters' ability to reallocate assets to alternative uses at a distance. High asset specificity is related to opportunism, referring to self-interested behaviour of WOFS operations employees at the expense of headquarters in this study (Williamson 1975). It is expected headquarters use control choices to minimise the risk of loss associated with opportunism, possibly more problematic and difficult to deal with at a distance.

The third activity trait in TCE theory is ex post hoc information impactedness, referring to the degree of asymmetry between headquarters and WOFS operations concerning performance achievements (Williamson 1979). Asymmetry can only be equalised between these two 
parties at a cost which is substantial in some cases (Williamson 1996). Such asymmetry may be particularly problematic and high concerning WOFS operations, given the distance from headquarters resulting in high ex post information impactedness. High ex post hoc information impactedness may lead to opportunistic behaviour by WOFS personnel, with higher probability of such behaviour at a distance, which headquarters needs to address.

It could be argued that activity traits (and the presence of human traits) do not capture the entirety of factors effecting control choices. While this is true, the advantage of applying the TCE theory perspective in this study is it may provide a parsimonious perspective on the instrumental factors effecting control choices, rather the fragmented approaches in literature.

\subsection{Management control archetypes and transaction cost economics}

Given activity traits appear to provide a relevant and parsimonious perspective on the WOFS operation context, we now need to consider the implications of these on the control choices of headquarters. Speklé's TCE of management control provides a conceptualisation of the link between activity traits and control choices. Our intention in this study is not to test Speklé's (2001) theory, but rather use it as a starting point to more holistically consider control choices in this context.

Speklé's (2001) framework consists of five control archetypes ${ }^{2}$, which are each aimed at addressing distinct control problems associated with different combinations of uncertainty, asset specificity and ex post hoc information impactedness (Williamson 1979, 2005). The choice of appropriate control archetype is argued to be the one that will economise the transaction costs associated with the domain of transactions (the WOFS in our study). In this

\footnotetext{
${ }^{2}$ Note that Speklé (2001) refers to nine control archetypes relating to market, hybrid and hierarchical organisational forms, but only five are relevant to hierarchical organisations (headquarters control of WOFS operations).
} 
section we detail the control archetypes and explain the expected associations with activity traits.

\section{Archetype 1: Arm's length control}

Arm's length control is characterised by headquarters extending high autonomy to WOFS management, within a framework of targets, monitoring, evaluation and rewards of subsidiary management according to market benchmarks. This archetype is appropriate, according to Speklé (2001), in situations of low uncertainty, where WOFS performance and activities can be specified ex ante, and moderate asset specificity ${ }^{3}$, allowing the use of market benchmarks. In this situation WOFS management decision making is likely to exhibit very little bounded rationality, due low uncertainty and specificity of performance and activities ex ante. In addition headquarters is likely to face little opportunism from WOFS operations due to the large number of headquarter options associated with resource reallocation, associated with moderate asset specificity (Williamson 1979). Accordingly Speklé (2001) argues extending high autonomy to WOFS management and monitoring, evaluating and rewarding based on market benchmarks is a sufficient means of control.

\section{$\underline{\text { Machine Control }}$}

Machine control archetype is appropriate where, according to Speklé (2001), uncertainty is relatively low and asset specificity is relatively high. High asset specificity means it is difficult for headquarters to deploy WOFS assets to alternative activities. Opportunistic WOFS management decisions further exacerbates the potential losses in a context of both limited alternative asset deployment opportunities and limited visibility of WOFS operations from the perspective of headquarters. The specificity of WOFS performance and activities ex ante, low uncertainty, by headquarters provides a means of using this archetype to mitigate

\footnotetext{
${ }^{3}$ In the context of hierarchical organisation, moderate asset specificity relates to relatively low levels of this activity trait. This is because assets of low specificity are usually the domain of the market based transactions. Accordingly in the content of hierarchical organisations, asset specificity ranges from moderate to high levels.
} 
opportunistic behaviour. According to Speklé's (2001) headquarters choice of either action or results oriented machine control is dependent on its ability to define output targets which are meaningful and sufficiently restrictive.

\section{Archetype 2: Results oriented machine control}

This archetype is characterised by extending high autonomy to WOFS management with an emphasis on providing direction through targets internally developed by headquarters. These form the basis of monitoring, evaluating and rewarding subsidiary management. This is argued to be appropriate in situations of high asset specificity, possible under low uncertainty, and, according to Kruis (2008) ${ }^{4}$, low ex post hoc information impactedness. Essentially Kruis (2008) extends the implications of Speklé’s (2001) argument, arguing that the choice of machine control is dependent on headquarter's ability to define meaningful and sufficiently restrictive output targets through the connection with ex post hoc information impactedness. If headquarters can define sufficiently restrictive administrative targets which address the risk associated with high asset specificity, this is a reflection of limited information asymmetry between WOFS management and headquarters concerning performance achievements, and results oriented machine control is the most relevant archetype according to Speklé (2001). Results oriented machine control is efficient from a headquarters' perspective, compared with the substantial costs of exercising action controls from a distance. Market benchmarks are not available where asset specificity is high due to the relative absence of comparable direct competitors performing similar activities (Anand and Singh 1997).

\footnotetext{
${ }^{4}$ Kruis (2008), one of the only studies outside this study to examine Speklé (2001) framework in a hierarchical context, provides a detailed explanation on the choice of either action or results oriented machine control according to the degree of ex post hoc information impactedness, which is limited in Speklé (2001).
} 


\section{Archetype 3: Action oriented machine control}

This archetype is characterised by relatively low to moderate autonomy extended to WOFS management and clear standardisation of behavioural expectations. Headquarters place strong importance on compliance with standardised behaviour, rules and procedures, through closely monitoring WOFS operations (Speklé 2001). It is argued to be appropriate in situations of relatively high asset specificity, protecting difficult to redeploy assets where there's the potential for opportunism, possible due to low uncertainty and, according to Kruis (2008) the only available archetype choice where ex post hoc information impactedness is high. High ex post hoc information impactedness means, there is significant asymmetry between headquarters and WOFS management concerning performance achievement, rendering results oriented machine control inoperative (Merchant and Van der Stede 2012; Keating 1997). The cost of exercising such control at a distance may be substantial; however, the benefits of mitigating the potential for opportunism in the context of foreign operations may be worthwhile (Williamson 1975).

\section{Archetype 4: Boundary control}

This archetype involves a high degree of autonomy being extended to WOFS management with clear guidelines concerning behaviour and activities not to be engaged in. Headquarters closely monitor compliance with these boundaries and take action against subsidiary management if they are breached. Essentially Speklé (2001) argues headquarters are limited to this archetype choice where uncertainty is relatively high, inability to specify WOFS performance and activities ex ante, and ex post hoc information impactedness is high, significant asymmetry between WOFS management and headquarters concerning performance achievement. In some cases, this archetype may be particularly relevant when controlling WOFS operations, due to the distance from headquarters (Hansen 2002; Schulz 2001). Defining the domain of responsibility minimises the risks associated with bounded 
rationality and/or opportunistic decisions as it prevents, theoretically, WOFS management from taking action or making decisions outside their domain of responsibility. Headquarters is argued to be limited to this archetype regardless of asset specificity levels, which is why this activity trait is argued not to affect the control choice in this case.

\section{Archetype 5: Exploratory control}

This archetype is characterised by high autonomy extended to WOFS management with relevant targets emerging and established during the period, forming the basis of monitoring and evaluating performance. There is significant emphasis placed on assessing and rewarding subsidiary management on the basis of long term performance. This archetype is argued to be appropriate in situations of relatively high uncertainty, due to the inability of headquarters to specify performance and activities of a WOFS ex ante and bounded rationality of decisions if headquarters attempted to do so (Williamson 1975). Further the use of this archetype is possible where ex post hoc information impactedness is low, due to limited asymmetry between WOFS management and headquarters concerning performance achievements. Accordingly this suggests headquarters are reliant on low levels of ex post hoc information impactedness as a means of controlling WOFS operations. Similarly to boundary control as above, headquarters only choice of control is argued to be limited to exploratory control in this case and the level of asset specificity is not expected to change this situation or the archetype choice.

Figure 1 below (adapted from Kruis, 2008) summarises the association between activity traits and control archetypes, as predicted by Speklé (2001). We examine whether these predictions are informative in explaining the control of WOFS operations by headquarters. 
Figure 1 - TCE theory of management control

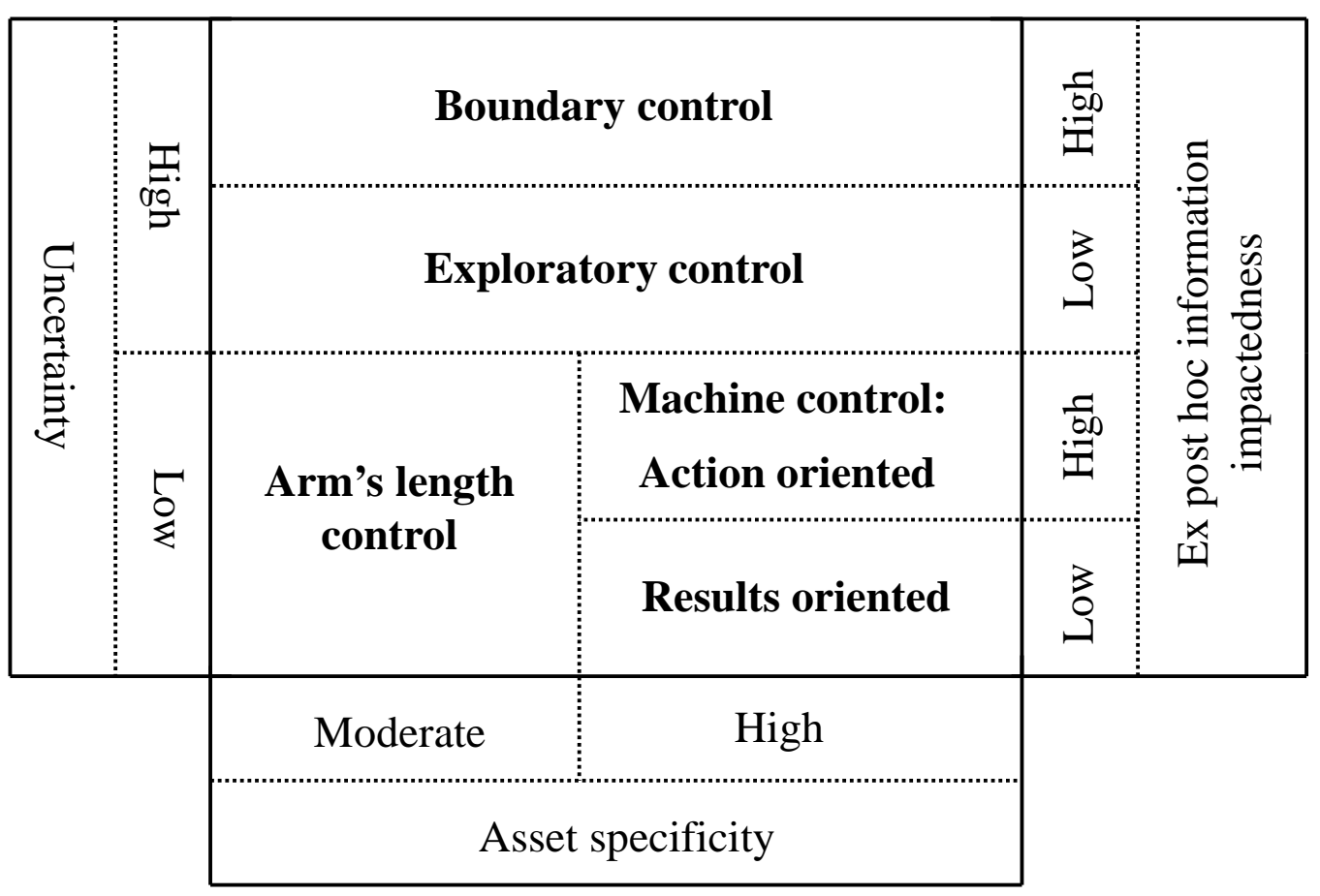

\subsection{Insights from exploratory interviews}

A number of exploratory interviews were conducted with senior managers at five firms involved in the control of WOFS operations to gain an insight into the applicability of the TCE theory of management control in this context. Firm selection was based on those expected to have unique sets of activity traits allowing a comprehensive initial investigation of the theory. These firms operated in industry sectors including pharmaceutical development and manufacturing, construction and development, finance, retail and medical product development. One semi-structured interview, lasting two to three hours, was conducted with a senior manager (including financial controllers, operations directors and chief executive officers) at each firm concerning their control of one particular WOFS.

Based on the exploratory interviews, a number of potential deviations from Speklé's (2001) conceptualisation are observed in the context of controlling WOFS operations. First, while the existence of the control archetypes is observed, multiple control archetypes appear to be 
adopted by headquarters. This contrasts with the single distinct archetype choices proposed by Speklé (2001). The distance between the headquarters and WOFS operations exemplifies control problems faced in some cases (Hassel and Cunningham 2004), suggesting control through multiple control archetypes is important. It is therefore more appropriate to consider headquarters exercising combinations of different control archetypes, rather than choosing one individual control archetype ${ }^{5}$.

The second deviation from Speklé's (2001) conceptualisation is certain activity trait levels, in combination with control archetype choices, do not align with Speklé's (2001) predictions. A number of control archetypes may be applicable to situations such as low uncertainty, rather than a single archetype being the appropriate choice. Accordingly, even though the associations proposed between activity traits and archetypes may be intended as the most economising method to deal with WOFS transactional activities, these predictions are questionable in this context. The challenges associated with operations at a distance, may be associated with a broader choice of control archetypes, facilitating tighter control. Further, given certain activity trait levels in isolation (or independently) appear associated with the use of multiple choice archetypes, this suggests considering the effect of combinations of activity traits on control archetype choices is not appropriate.

The interviews indicate, despite the deviations being observed, Speklé's (2001) theory is applicable and useful in conceptualising the control choices and the activity traits that appear to explain variation in these choices. Given our intention in this study is not to test Speklé's (2001) TCE theory of management control, but rather use it as a starting point and means of explaining the control of WOFS operations, the deviations concerning the use of multiple control archetypes and the independent effect of activity traits on control archetype choices

\footnotetext{
${ }^{5}$ We recognise that Speklé (2001) suggests that archetypes are exclusive control choices and perhaps a combination of archetypes can also be thought of a "control package". However, for the purposes of simplicity we refer to these as "combinations of control archetypes".
} 
have important implications on the research method, the regression analysis, appropriate when examining this context.

\section{Evidence from statistical analysis}

\subsection{Survey method and responses}

Data collected through a cross-sectional survey ${ }^{6}$, following the guidance of Dillman (2000) and suggests of literature (Tung 2000), enables statistical modelling of the associated between activity traits and control choices. Respondents were asked to complete the survey with regard to the management of one WOFS they (headquarters) control. A total of 178 surveys were returned, providing a response rate of 28.80 per cent. After removing nine incomplete surveys and ten relating to subsidiaries with zero employees (dormant subsidiaries) where control is not relevant, 159 usable surveys remained. ${ }^{7}$ Respondents appeared to be at the company an adequate period of time (mean 9.58 years) to be sufficiently knowledgeable to answer the questions. There is a large variation in the size of both subsidiaries (1-5,000 employees) and corporations (5-38,000 employees), indicating that a broad range of firms replied to the survey. We include a size control variable in our models to account for variation in control choices according to this variable (explained later in this section). The industry classification of the final sample firms, reported in Panel A of Table 1, and WOFS locations, reported in Panel B of Table 1, are representative of Australian

\footnotetext{
${ }^{6}$ The survey instrument is available upon request from the corresponding author.

${ }^{7}$ The means and standard deviations of the constructs are compared based on early and late respondents (first and last 40 per cent respectively of useable responses which provided a clear distinction between the initial survey mail out and the later follow up stages). The means of the constructs for early and late respondents are not significantly different, similar as confirmed by the' $t$ ' statistics, notwithstanding asset specificity where the difference is statistically significant. This difference may be due to the relative ease of contacting managers at headquarters with more asset specific operations, due to the greater risks and consequently closer focus on operations. However, in any case, the size of this difference may not be economically significant and, given all other constructs, are not significantly different we assume that there is no systematic bias in our data.
} 
business involvement. ${ }^{8}$ The diversity of WOFS operations in our sample is expected to be associated with a large variation in activity traits and associated problems.

\section{[INSERT TABLE 1 HERE]}

\subsection{Evidence on control choices}

While the interviews suggest headquarters choose multiple rather than individual archetypes to control a WOFS, the different sets of control mechanisms chosen appear aligned with the archetype conceptualisations. Accordingly there are different combinations of control archetypes exercised and we measure the degree to which these are represented, rather than identify one particular archetype headquarters selects in each case. The survey questions and indicators to operationalise the different archetypes, as conceptualised by Speklé (2001), are adapted from Kruis (2008). Kruis’ (2008) survey questions and indicators directly relate to the measurement of Speklé's (2001) framework and in this study are adapted to the context of controlling WOFS operations. The control archetype indicators are summarised in Table 2. The indicators measure the extent to which headquarters choose a particular control archetype and are reflective indicators. The ticked boxes indicate the proposed management control indicators of each control archetype listed across the top of the table.

\section{[INSERT TABLE 2 HERE]}

To test whether there are a number of different management control archetypes in use, we utilise Principal Component Analysis (PCA) (Jarvis, Mackenzie, and Podsakoff 2003). Items which have lower than acceptable rotated factor loadings and PCA communalities (generally lower than 0.5 ) are removed from the factor analysis. The final factor loadings and PCA

\footnotetext{
${ }^{8}$ Nevertheless we rerun our tests excluding mining companies from the sample and the results do not significantly change.
} 
communities, reported in Table 3, are high in most cases, with those remaining closely describing the main and unique characteristics of each control archetype.

\section{[INSERT TABLE 3 HERE]}

The internal consistency of each control archetype construct, with the reflective indicators (composite reliability), is assessed through using Cronbach's Alpha (Cronbach 1951). All Cronbach Alpha values are higher or close to 0.70, reported in Table 4, indicating the control archetype constructs have acceptable composite reliability and the control archetypes are valid representations of different sets of control choices.

\section{[INSERT TABLE 4 HERE]}

Both the individual PCA and composite reliability statistics indicate that the five control archetypes appear to be representative of the sets of control choices exercised.

The discriminant validity of the control archetypes relates to the ability to discriminate a set of indicators measuring one construct from those of other constructs (more variance is shared between the indicators of a construct than any other indicators representing a different construct). It is assessed by comparing the square root of the average variance extracted (AVE) to the correlations between each construct (Fornell and Larcker 1981), presented in Table 5 below. If the square root of the AVE for a construct is higher than the correlations with other constructs, this indicates acceptable discriminant validity.

\section{[INSERT TABLE 5 HERE]}

The value of the square root of AVE for each construct (values in bold) is higher than the Pearson correlations between all constructs, with the exception of action oriented machine 
and boundary control. Accordingly it may be problematic to discriminate between action oriented machine and boundary control, given they are relatively direct forms of control.

The results of the factors analysis, composite reliability and discriminant validity testing, indicate the control archetypes conceptualised by Speklé (2001) are representative of distinct control archetypes. However, it is important to note these results suggest limits to the degree the archetypes are single independent control choices, as indicated by the lower discriminant validity statistics in some cases. This is consistent with the interview suggestions, that multiple archetypes are used.

\subsection{Associations between activity traits and control archetype choice}

In order to measure both the activity traits and the control archetype constructs, the relevant indicators are combined through simple additive aggregation, consistent with the control archetype constructs. Each activity trait is defined and measured as follows:

i. Uncertainty: The specificity of performance and activities (ex ante) relates to the degree headquarters can provide direction consistent with the goals and objectives of the WOFS operations. Ambiguous goals and objectives are associated with limited headquarters' knowledge of WOFS activities, and accordingly high uncertainty. To measure uncertainty, indicators are adapted from Kruis (2008) and Rainey (1983) based on headquarters degree of clarity in these four areas: clarity of goals; specificity of goals; clarity of goals to outsiders; and goals known to insiders.

ii. Asset specificity: Both human and physical asset specificity are relevant in the context of international operations (Klein, Frazier, and Roth 1990; Sridharan and Akroyd 2011). Intangible assets relating to branding and product expertise are also relevant in the contemporary business context (Henri 2006). Accordingly, the following indicators are used to measure asset specificity based on the extent the following 
factors can be redeployed to alternative uses if WOFS operations cease: employee skills (human); training of employees (human); physical assets (physical assets); technological systems (physical assets); product customisation expertise (product); and reputational capital (brand name).

iii. Ex post hoc information impactedness: Ex post hoc information impactedness is measured based on the relative information headquarters has compared with WOFS management concerning performance achievements, thereby measuring asymmetry. This is measured using the following indicators, concerning headquarters relative information of WOFS operations compared with subsidiary management, adapted from Dunk (1993): activities undertaken by subsidiary; operational processes performed by subsidiary; realisation of subsidiary performance potential; impact of external factors on performance; and understanding subsidiary achievements.

The validity of these activity trait constructs was examined through conducting a factor analysis of the indicators to determine the composite reliability and discriminant validity (including control archetype constructs). These statistics indicate the constructs are valid, expected given the well-established nature of these measures. Descriptive statistics of the constructs, minimum, maximum and standard deviation statistics indicate there is significant variation in the data, and no significant floors or ceiling in the data. This alleviates any possible concern of limited variation in activity traits and control archetypes due to the focus on the WOFS operations context.

A series of ordinary least squares (OLS) regressions are run, consistent with insights gained from the interviews conducted. These OLS regressions using continuous variables, based on the simple additive aggregation of indicators for each construct, are appropriate as they allow the effect of varying levels of independent activity traits on control archetypes choices to be 
examined. Higher construct values indicate higher levels of an activity trait or greater use of a control archetype.

The association between activity traits and arm's length control is tested using Equation 1. Significant and negative coefficients for $\alpha_{1}$ (uncertainty) and $\alpha_{2}$ (asset specificity) indicate support for Speklé’s (2001) arguments. Moderate asset specificity is argued to be associated with arm's length control; in the hierarchical organisational context this indicates asset specificity is relatively low as low asset specificity is applicable to market based transactions. Accordingly this is why a negative coefficient is predicted concerning $\alpha_{2}$ (asset specificity).

ARM_CONTROL $L_{i}=\alpha_{0}+\alpha_{1}$ UNCERTAINTY $_{i}+\alpha_{2}$ ASSET_SPEC $_{i}+\alpha_{3} S I Z E i+\varepsilon_{i}$

The association between activity traits and results oriented machine control is tested using Equation 2. A significant and negative coefficient for $\alpha_{1}$ (uncertainty), significant positive coefficient for $\alpha_{2}$ (asset specificity), and significant negative coefficient for $\alpha_{3}$ (ex post hoc information impactedness), indicates support for Speklé’s (2001) arguments.

$$
\begin{aligned}
& \text { RESULTS_CONTROL }_{i}=\alpha_{0}+\alpha_{1} \text { UNCERTAINTY }_{i}+\alpha_{2} \text { ASSET_SPEC }_{i}+ \\
& \alpha_{3} E X \_P O S T \_H O C \_I N F O \_I M P A C_{i}+\alpha_{4} S I Z E i+\varepsilon_{i}
\end{aligned}
$$

The association between activity traits and action oriented machine control is tested using Equation 3. A significant and negative coefficient for $\alpha_{1}$ (uncertainty), significant positive coefficient for $\alpha_{2}$ (asset specificity), and significant positive coefficient for $\alpha_{3}$ (ex post hoc information impactedness), indicates support for Speklé’s (2001) arguments. 


$$
\begin{aligned}
& \text { ACTION_CONTROL } i=\alpha_{0}+\alpha_{1} \text { UNCERTAINTY }_{i}+\alpha_{2} \text { ASSET_SPEC }_{i}+\alpha_{3} \text { EX_POST }_{-} \\
& \text {HOC_INFO_IMPAC } i \\
& +\alpha_{4} \text { SIZE }_{i}+\varepsilon_{i}
\end{aligned}
$$

The association between activity traits and boundary control is tested using Equation 4. Significant positive coefficients for both $\alpha_{1}$ (uncertainty) and $\alpha_{2}$ (ex post hoc information impactedness) indicate support for Speklé’s (2001) arguments.

$$
\begin{aligned}
& \text { BOUNDARY_CONTROL } L_{i}=\alpha_{0}+\alpha_{1} \text { UNCERTAINTY }_{i}+\alpha_{2} \text { EX_POST_HOC_INFO_ }_{-} \\
& \text {IMPAC }_{i}+\alpha_{3} \text { SIZE }_{i}+\varepsilon_{i}
\end{aligned}
$$

The association between activity traits and exploratory control is tested using Equation 5. A significant positive coefficient for $\alpha_{1}$ (uncertainty) and significant negative coefficient for $\alpha_{2}$ (ex post hoc information impactedness) indicate support for Speklé’s (2001) arguments.

$$
\begin{aligned}
& \text { EXPLORATORY_CONTROL }{ }_{i}=\alpha_{0}+\alpha_{1} \text { UNCERTAINTY } i+\alpha_{2} \text { EX_POST_HOC_ } \\
& \text { INFO_IMPAC }_{i}+\alpha_{3} \text { SIZE }_{i}+\varepsilon_{i}
\end{aligned}
$$

Not all activity traits are included in all equations (ex post hoc information impactedness concerning arm's length control and asset specificity concerning boundary and exploratory control) as they are not relevant in determining the choices of control (Speklé 2001).

SIZE is based on the total number of employees (including the focal WOFS) of the whole corporation the headquarters is controlling. Literature indicates size is an important control variable (Chenhall 2003). We do not include other control variables. The activity traits in TCE theory are argued to be a parsimonious, yet comprehensive enough to explain the control archetypes choices.

The OLS regression results, examining whether activity traits determine the choice of management control archetypes, are reported in Table 6. 
[INSERT TABLE 6 HERE] 
Arm's length control - Equation 1

The coefficients concerning both uncertainty $\left(\alpha_{1}=-0.414, t=-1.786\right)$ and asset specificity $\left(\alpha_{2}=-0.052, t=-0.653\right)$ are negative, consistent with predictions. While the uncertainty coefficient is significant at the 10 per cent level, the asset specificity coefficient is insignificant at all conventional levels. The F-statistic (1.978) indicates the model does not have significant predictive ability at conventional levels and the variation in control archetype use explained is quite low $\left(R^{2}=0.018\right)$. Accordingly there is little support for the predictions.

Results oriented machine control - Equation 2

All results concerning the coefficients are insignificant (uncertainty: $\alpha_{1}=-0.042, \mathrm{t}=$ -0.550 ; asset specificity: $\alpha_{2}=-0.045, \mathrm{t}=-0.595$; ex post hoc information impactedness: $\alpha_{3}=$ $-0.029, \mathrm{t}=-0.378$ ) with the exception of subsidiary size (control variable, $\alpha_{4}=0.313, \mathrm{t}=$ 4.041). Accordingly there is no support for the predictions; however larger corporations rely more heavily headquarters on results oriented machine control. The F-statistic (4.321) indicates the model does have significant predictive ability and the $R^{2}$ is 0.078 .

Action oriented machine control - Equation 3

The results indicate uncertainty $\left(\alpha_{1}=-0.249, \mathrm{t}=-3.442\right)$ is negatively and significantly associated with action oriented machine control, consistent with predictions. Further, both asset specificity $\left(\alpha_{2}=-0.141, \mathrm{t}=-1.957\right)$ and ex post hoc information impactedness $\left(\alpha_{3}=\right.$ $-0.294, \mathrm{t}=-4.036)$ are negatively and significantly associated with this control archetype, opposite to Speklé's (2001) predictions. The relatively high F-statistic (10.098) and $R$ square (0.187) indicates the model has significant predictive ability and explanatory power.

\section{Boundary control - Equation 4}

The results indicate uncertainty $\left(\alpha_{1}=-0.302, \mathrm{t}=-4.164\right)$ and ex post hoc information impactedness $\left(\alpha_{2}=-0.280, \mathrm{t}=-3.824\right)$ are negatively and significantly associated with 
boundary control use, the opposite of Speklé's (2001) predictions. The model has high predictive ability and explanatory power indicated by the $F$-statistic (12.623) and $R$ squared (0.181).

\section{Exploratory control - Equation 5}

The results indicate ex post hoc information impactedness $\left(\alpha_{2}=-0.246, \mathrm{t}=-3.205\right)$ is significantly negatively associated with exploratory control, consistent with predictions. Uncertainty ( $\left.\alpha_{1}=-0.175, \mathrm{t}=-2.262\right)$ is also negatively and significantly associated with exploratory control, the opposite of Speklé's (2001) predictions. The F-statistic (5.778) indicates the model does have significant predictive ability and the $R^{2}$ is 0.083 .

The results indicate some support for Speklé's (2001) predictions and the appropriateness of taking into account the deviations observed from the original conceptualisation in the regression design. While our intention in this study is to examine headquarters' control of WOFS operations, rather than a direct test of Speklé's (2001) original theory, a direct test would serve the purpose of demonstrating whether or not our modified version of Speklé's (2001) theory is more relevant in explaining control choices in this context. Accordingly, before discussing these results further, Speklé's (2001) original theory is tested next.

\section{Additional testing}

Speklé (2001) argues particular combinations of activity traits are associated with distinct control archetypes. Accordingly, to directly test the original theory, it is important to identify whether or not headquarters are using a particular control archetype and to determine the association of this choice with the combined variation of activity traits. Consistent with Speklé (2001), and to test whether control archetypes are determined by combinations of activity traits, we formulate the following multinominal logistic regression: 


$$
\begin{aligned}
& \text { CONTROL_ARCHETYPE }=\alpha_{0}+\alpha_{1} \text { AT_INTERACTION }{ }_{i}+\alpha_{2} \text { UNCERTAINTY }_{i}+ \\
& \alpha_{3} \text { ASSET_SPEC }_{i}+\alpha_{4} \text { EX_POST_HOC_INFO_IMPAC }{ }_{i}+\alpha_{5} \text { SIZE }_{i}+\varepsilon_{i}
\end{aligned}
$$

where:

CONTROL_ARCHETYPE is a dependent variable classifying which control archetype headquarters primarily exercises. To determine which archetypes is the primary type exercised, the construct values of all archetypes are compared to find the highest one. This dependent variable is then coded accordingly (1-5, relating to each control archetype) to identify which control archetype is primarily exercised ${ }^{9}$.

AT_INTERACTION is included in the multinational logistic regression as an interaction variable, defining situations where Speklé (2001) argues particular control archetypes are appropriate. This variable is based on the result of multiplying together activity trait constructs relevant in the determination of a particular control archetype choice. High variable values indicate situations where Speklé (2001) argues a particular control archetype is appropriate. Certain activity trait constructs are reversed to calculate this variable, so that a higher value reflects a situation where a particular control archetype is argued by Speklé (2001) to be appropriate.

The results ${ }^{10}$ indicate that while the model chi-squares are significant and more than 50 per cent of control archetypes are correctly classified, the independent activity trait interaction variable is insignificant in all models with the exception of exploratory control use relative to arm's length control (Coefficient -1.881, Wald 3.056, significant at the 10\% level). While

\footnotetext{
${ }^{9} T$-tests confirm the construct values for the primary control archetype are higher than the non-primary archetype when compared on an individual control archetype construct basis and all control archetype construct basis.

${ }^{10}$ In the interests of maintaining the length of this paper to an acceptable level, the results of the additional testing are not reported in table form. However these results tables are all available from the authors by request.
} 
some of the independent activity trait variables are significant, there is little alignment with Speklé's (2001) predictions. The results indicate Speklé's (2001) original theory is not supported in the context of headquarters controlling WOFS operations.

Given almost all of the activity trait interaction variables are insignificant, the models are rerun excluding the interaction variables. A greater number of independent activity trait variable coefficients are significant, however the percentage of control archetypes correctly classified (while high in some cases) is zero for the control archetypes of arm's length and action control. The interview analysis suggests headquarters use different combinations of control archetypes, so the fact that some are have zero percentage correctly classified is problematic. The identification of the control archetype headquarters use to the greatest extent does not appear to be appropriate or effective in capturing the true associations.

A series of further models are also run to examine whether there are alternative and possibly more appropriate ways of interpreting, applying and testing Speklé's (2001) theory to understand the control of WOFS operations. We re-run the OLS regression models (in section 3 above) with the inclusion of the activity trait interaction variables, run binary logistic regressions with a dependent dummy variable based on whether not a control archetype is used as the primary choice of control and an OLS regression with the dependent continuous variable based on the extent one control archetype is exercised relative to others. The results of the additional testing indicate the OLS regression model results, presented in Table 6, are the most significant set of results. 


\section{Results discussion}

The first set of OLS regression results, taking into account the deviations observed from Speklé's (2001) original conceptualisation, are the most significant set of results. This is consistent with the insights and suggestions from the exploratory interviews. The results are now discussed.

\section{Arm's length control}

The regression results indicate, regardless of activity trait coefficients and significance levels, the arm's length control model is insignificant according to the F-stat. This may be related to the context of controlling operations from a distance, where the redeployment of assets is more difficult, and relying on arm's length control as the basis of directing asset use and protection may be not adequate or appropriate in this context (Teece, Shuen, and Pisano 1997; Hansen 1999; Nilsson 2002). Further, arm’s length control involves the establishment of relevant benchmarks and the distance separating headquarters from subsidiary operations means establishing these benchmarks may not be practical compared with home country operations (Zaheer and Mosakowski 1997). As observed in the interviews, Speklé's (2001) theory may not apply uniformly to all contexts. Headquarters may not consider arm's length control effective, particularly concerning the protection of assets, explaining the insignificance of the arm’s length control model.

\section{Results oriented machine control}

The lack of significant results for model two could be explained by the wide spread use of results oriented machine control as means of control (Sandino 2007), consistent with elements of this archetype notable in a number of the firms where managers were interviewed. Results oriented machine control may provide one of the few means of clear objective communication of subsidiary performance available when controlling from a 
distance (Argyres 1995). The descriptive statistics in this study confirms the widespread use in this context, while there substantial variability in the choice of results oriented machine control (Likert scale choice ranging from 2.097 to 5.000 ), the mean choice is 4.150 which is relatively high. It appears headquarters are willing to invest in this control given the expected benefits of clear objective communication of performance, even though it appears inconsistent with activity traits observed.

\section{Action oriented machine control}

Consistent with predictions, uncertainty is significantly and negatively associated with action oriented machine control. Further, it is predicted asset specificity is positively associated with action oriented machine control, particularly given the difficulties of redeploying high specific assets at a distance (Chandler 1991). The results are opposite to predictions, suggesting headquarters doesn’t have sufficient knowledge, resources or confidence to effectively direct the use of highly specific assets at a distance (Monteiro, Arvidsson, and Birkinshaw 2008; Zaheer and Mosakowski 1997). This suggests it is more appropriate to extend WOFS management autonomy, given their proximity and relative ability to protect and maximise asset returns.

The results also indicate headquarters exercise action oriented machine control to a greater extent where ex post hoc information impactedness low, opposite to Speklé's (2001) predictions. Speklés (2001) argument is based on the comparatively lower costs of results oriented machine control, but disregards the effectiveness of action oriented machine control in situations of low ex post hoc information impactedness. Results suggest headquarters use performance information associated with low ex post hoc information impactedness to make more informed action control oriented machine control choices. Accordingly the feedback 
loop concerning results oriented machine controls (Merchant and Van der Stede 2012) may also apply to action oriented machine control use in this context.

\section{Boundary control}

The negative association with uncertainty and ex post hoc information impactedness is the opposite of Speklé's (2001) predictions. Accordingly, this suggests the ability to exercise this control archetype may be possible where uncertainty and ex post hoc information impactedness is low. Setting inappropriate boundaries where headquarters lacks the ability to specify the performance and activities of subsidiary activities and performance may significantly impede the autonomy of subsidiary management, particularly at a distance, to maximise returns from operations (Merchant and Van der Stede 2012). Considering the consequences of inappropriate boundaries, the use of boundary control in situations of low uncertainty and ex post hoc information impactedness appears appropriate.

\section{Exploratory control}

The negative association with uncertainty is the opposite of Speklé's (2001) predictions, suggesting the ability to set and monitor relevant targets throughout a period is associated with headquarters’ knowledge of subsidiary operations (Ouchi 1979). Accordingly, rather than headquarters being limited to exploratory control where uncertainty is high, the ability to exercise this control archetype is possible where uncertainty is low.

\section{Summary and conclusions}

Applying Speklé's (2001) TCE theory of management control as a starting point in this study aids the examination of headquarters' control of WOFS operations. Two aspects of this theory that are applied to examine this context. First, whether different control choices are characterised by the control archetype choices proposed by Speklé (2001). Second, whether the choice of control is a function of the economic characteristics (activity traits) of the firm. 
We conducted a series of interviews to provide insights into the applicability of the TCE theory of management control in this context and subsequently statistically analysed crosssectional survey data. The interviews facilitated the identification of a number of potential deviations from Speklé's (2001) theory. In particular these relate to the use of combinations of multiple control archetypes and the independent effects of activity traits (low uncertainty and ex post hoc information impactedness) on the use of these archetypes. The regression results indicate when taking into account multiple control archetypes are exercised by headquarters and the independent effects of activity traits on these choices, TCE theory and Speklé (2001) conceptualisation were relevant in explaining the control choices of headquarters. A number of alternative regression modelling approaches to test Speklé's (2001) theory are conducted, with few significant results observed.

While the activity traits may not have been as comprehensive as expected in explaining headquarters control choices, they still appear to be a parsimonious and informative. The selection of multiple control archetypes to control WOFS operations appears important in this context, given the challenges associated with WOFS operations at a distance. It would be interesting to examine the effect of these control choices on performance in a future study (Speklé and Verbeeten 2013). This would confirm whether the use of multiple archetypes is an efficient and effective control choice. 


\section{References}

Abernethy, M. A., W. F. Chua, P. F. Luckett, and F. H. Selto, 1999, Research in managerial accounting: Learning from others' experiences, Accounting and Finance 39, 1-27.

Anand, J., and H. Singh, 1997, Asset redeployment, acquisitions and corporate strategy in declining industries, Strategic Management Journal 18, 99-118.

Argyres, N., 1995, Technology strategy, governance structure and interdivisional coordination, Journal of Economic Behavior and Organization 28, 337-358.

Benson, K., P. M. Clarkson, T. Smith, and I. Tutticci, Forthcoming, A review of accounting research in the Asia Pacific region, Australian Journal of Management.

Benson, K., R. Faff, and T. Smith, 2014, Fifty years of finance research in the Asia Pacific Basin, Accounting and Finance 54, 335-363.

Bogaard, M. A. v. d., and R. F. Speklé, 2003, Reinventing the hierarchy: Strategy and control in the Shell Chemicals carve-out, Management Accounting Research 14, 79-93.

Bourmistrov, A., and K. Kaarbøe, 2013, From comfort to stretch zones: A field study of two multinational companies applying "beyond budgeting” ideas, Management Accounting Research 24, 196-211.

Chalos, P., and N. O'Connor, 2004, Determinants of the use of various control mechanisms in US-Chinese joint ventures, Accounting, Organizations and Society 29, 591-608.

Chandler, A. D., 1991, The functions of the HQ unit in the multibusiness firm, Strategic Management Journal 12, 31-50.

Chenhall, R. H., 2003, Management control systems design within its organizational context: findings from contingency-based research and directions for the future, Accounting, Organizations and Society 28, 127-168.

Chenhall, R. H., and D. Smith, 2011, A review of Australian management accounting research: 1980-2009, Accounting and Finance 51, 173-206. 
Colombage, S. R. N., A. Gunasekarage, and S. M. M. Shams, 2014, Target’s organisational form and returns to Australian bidders in cross-border acquisitions, Accounting and Finance 54, 1063-1091.

Cronbach, L. J., 1951, Coefficient alpha and the internal structure of tests, Psychometrika 16, 297-334.

Dillman, D., 2000, Mail and internet surveys: The tailored design method (John Wiley, New York ; Chichester).

Dossi, A., and L. Patelli, 2008, The decision-influencing use of performance measurement systems in relationships between headquarters and subsidiaries, Management Accounting Research 19, 126-148.

Dunk, A., 1993, The effects of budget emphasis and information asymmetry on the relation between budgetary participation and slack, The Accounting Review 68, 400-410.

Eden, L., and S. R. Miller, 2004, Distance matters: Liability of foreignness, institutional distance and ownership strategy, Advances in international management 16, 187-221.

Emsley, D., and F. Kison, 2007, The relationship between trust and control in international joint ventures: evidence from the airline industry, Contemporary Accounting Research 24, 829-858.

Fornell, C., and D. F. Larcker, 1981, Evaluating structural equation models with unobservable variables and measurement error, Journal of Marketing Research 18, $39-50$.

Forsgren, M., T. Pedersen, and N. J. Foss, 1999, Accounting for the strengths of MNC subsidiaries: the case of foreign-owned firms in Denmark, International Business Review 8, 181-196.

Hansen, M., 2002, Knowledge networks: Explaining effective knowledge sharing in multiunit companies, Organization Science 13, 232- 248. 
Hansen, M. T., 1999, The search-transfer problem: The role of weak ties in sharing knowledge across organization subunits, Administrative Science Quarterly 44, 82111.

Hassel, L. G., and G. M. Cunningham, 2004, Psychic distance and budget control of foreign subsidiaries, Journal of International Accounting Research 3, 79-93.

Henri, J., 2006, Management Control systems and strategy: A resource-based perspective, Accounting, Organizations and Society 31, 529-558.

Jarvis, C. B., S. B. Mackenzie, and P. M. Podsakoff, 2003, A critical review of construct indicators and measurement model misspecification in marketing and consumer research, Journal of Consumer Research 30, 199-218.

Jaussaud, J., and J. Schaaper, 2006, Control mechanisms of their subsidiaries by multinational firms: a multidimensional perspective, Journal of International Management 12, 23-45.

Keating, A. S., 1997, Determinants of divisional performance evaluation practices, Journal of Accounting and Economics 24, 243-274.

Klein, S., G. L. Frazier, and V. J. Roth, 1990, A transaction cost analysis model of channel integration markets, Journal of Marketing Research 27, 196-208.

Kruis, A., 2008, Management control system design and effectiveness, $\mathrm{PhD}$ thesis (Nyenrode Business Universiteit).

Malmi, T., and D. A. Brown, 2008, Management control systems as a packageopportunities, challenges and research directions, Management Accounting Research 19, 287-300.

Mason, R. B., 2007, The external environment's effect on management and strategy, Management Decision 45, 10-28. 
Merchant, K. A., 2012, Making management accounting research more useful, Pacific Accounting Review 24, 334-356.

Merchant, K. A., and W. A. Van der Stede, 2012, Management control systems: Performance measurement, evaluation and incentive (Prentice Hall).

Moilanen, S., 2007, Knowledge translation in management accounting and control: A case study of a multinational firm in transitional economies, European Accounting Review 16, 757-789.

Monteiro, L. F., N. Arvidsson, and J. Birkinshaw, 2008, Knowledge flows within multinational corporations: Explaining subsidiary isolation and its performance implications, Organization Science 19, 90-107.

Nilsson, F., 2002, Strategy and management control systems: A study of the design and use of management control systems following takeover, Accounting and Finance 42, 4171.

Ouchi, W. G., 1979, A conceptual framework for the design of organizational control mechanism, Management Science 25, 833-848.

Rainy, H. G., 1983, Public agencies and private firms; incentive structures, goals, and individual roles, Administration and Society 15, 207-242.

Rindfleisch, A., and J. Heide, 1997, Transaction cost analysis: Past, present and future applications, Journal of Marketing 61, 30-54.

Sandelin, M., 2008, Operation of management control practices as a package-A case study on control system variety in a growth firm context, Management Accounting Research 19, 324-343.

Sandino, T., 2007, Introducing the first management control systems: Evidence from the retail sector, The Accounting Review 82, 265-293. 
Schulz, M., 2001, The uncertain relevance of newness: Organizational learning and knowledge flows, Academy of Management Journal 44, 661-681.

Simon, H. A., 1945, Adminstrative behavior (New York: Free Press).

Speklé, R. F., 2001, Explaining management control structure variety: a transaction cost economics perspective, Accounting, Organizations and Society 26, 419-441.

Speklé, R. F., and F. H. M. Verbeeten, 2013, The use of performance measurement systems in the publicsector: Effects on performance, Management Accounting Research 25, 131-146.

Spicer, B., and V. Ballew, 1983, Management accounting systems and the economics of internal organization, Accounting, Organizations and Society 8, 73-96.

Sridharan, V., and C. Akroyd, 2011, The integration substitute: the role of controls in managing human asset specificity, Accounting and Finance 51, 1055-1086.

Tallman, S., and K. Fladmoe-Lindquist, 2002, Internationalization, globalization, and capability-based strategy, Calfornia Management Review 45, 116-135.

Teece, D. J., A. Shuen, and G. Pisano, 1997, Dynamic capabilities and strategic management, in N. J. Foss ed, Resources, firms, and strategies: A reader in the resource-based perspective (Oxford University Press, Oxford).

Tung, S., 2000, Environmental accounting in the New Zealand contracting industry: Comments on the use of mail survey method, Pacific Accounting Review 12, 1-15.

Williamson, O. E., 1975, Markets and Hierarchies (New York: Free Press).

Williamson, O. E., 1979, Transaction-cost economics: The governance of contractual relations, The Journal of Law and Economics 22, 234-235.

Williamson, O. E., 1996, The mechanisms of governance (New York: Oxford University Press). 
Williamson, O. E., 2005, Transaction cost economics and business administration, Scandinavian Journal of Management 21, 19-40.

Zaheer, S., and E. Mosakowski, 1997, The dynamics of the liability of foreignness: A global study of survival in financial services, Strategic Management Journal 18, 439-464. 
Table 1 - Respondent characteristics

Panel A - Industry classification of sample firms

\begin{tabular}{|c|c|c|c|c|}
\hline \multirow[t]{2}{*}{ Industry } & \multicolumn{2}{|c|}{ Corporation } & \multicolumn{2}{|c|}{ Subsidiary } \\
\hline & Frequency* & Percentage & Frequency* & Percentage \\
\hline Mining & 46 & $20.4 \%$ & 37 & $18.5 \%$ \\
\hline Manufacturing & 38 & $16.8 \%$ & 27 & $13.5 \%$ \\
\hline Other Services & 26 & $11.5 \%$ & 26 & $13.0 \%$ \\
\hline Professional, Scientific \& Technical & & & & \\
\hline Services & 18 & $8.0 \%$ & 19 & $9.5 \%$ \\
\hline Information Media \& & & & & \\
\hline Telecommunications & 16 & $7.1 \%$ & 15 & $7.5 \%$ \\
\hline Finance \& Insurance Services & 13 & $5.8 \%$ & 12 & $6.0 \%$ \\
\hline Wholesale Trade & 13 & $5.8 \%$ & 16 & $8.0 \%$ \\
\hline Construction & 11 & $4.9 \%$ & 10 & $5.0 \%$ \\
\hline Electricity, Gas, Water \& Waste Services & 8 & $3.5 \%$ & 8 & $4.0 \%$ \\
\hline Retail Trade & 7 & $3.1 \%$ & 5 & $2.5 \%$ \\
\hline Agriculture, Forestry \& Fishing & 6 & $2.7 \%$ & 5 & $2.5 \%$ \\
\hline Health Care \& Social Assistance & 6 & $2.7 \%$ & 6 & $3.0 \%$ \\
\hline Transport, Postal \& Warehousing & 6 & $2.7 \%$ & 4 & $2.0 \%$ \\
\hline Administrative \& Support Services & 5 & $2.2 \%$ & 4 & $2.0 \%$ \\
\hline Rental, Hiring \& Real Estate Services & 3 & $1.3 \%$ & 4 & $2.0 \%$ \\
\hline Accommodation \& Food Services & 1 & $0.4 \%$ & 0 & $0.0 \%$ \\
\hline Arts \& Recreation Services & 1 & $0.4 \%$ & 1 & $0.5 \%$ \\
\hline Education \& Training & 1 & $0.4 \%$ & 1 & $0.5 \%$ \\
\hline Public Administration \& Safety & 1 & $0.4 \%$ & 0 & $0.0 \%$ \\
\hline
\end{tabular}

Panel B - Subsidiary location

\begin{tabular}{lcc}
\hline \multicolumn{1}{c}{ Region } & Frequency & Percentage \\
\hline North America & 42 & $26.42 \%$ \\
Asia & 34 & $21.38 \%$ \\
Oceania & 34 & $21.38 \%$ \\
Europe & 27 & $16.98 \%$ \\
Africa & 16 & $10.06 \%$ \\
Middle East & 4 & $2.52 \%$ \\
South America & 2 & $1.26 \%$ \\
\hline
\end{tabular}


Table 2 - Proposed indicators of control archetypes

\begin{tabular}{|c|c|c|c|c|c|c|c|}
\hline Dimensions & & Indicators & $\begin{array}{l}\text { Arm's } \\
\text { length } \\
\text { control }\end{array}$ & $\begin{array}{c}\text { Results } \\
\text { oriented } \\
\text { machine } \\
\text { control }\end{array}$ & $\begin{array}{c}\text { Action } \\
\text { oriented } \\
\text { machine } \\
\text { control }\end{array}$ & $\begin{array}{l}\text { Boundary } \\
\text { control }\end{array}$ & $\begin{array}{c}\text { Exploratory } \\
\text { control }\end{array}$ \\
\hline \multirow{4}{*}{ Structure } & 1 & $\begin{array}{l}\text { Accountability/responsibil } \\
\text { ities defined }\end{array}$ & & $\checkmark$ & $\checkmark$ & & \\
\hline & 2 & $\begin{array}{l}\text { Autonomy extended to } \\
\text { subsidiary management }\end{array}$ & $\checkmark$ & $\checkmark$ & $\checkmark($ reversed $)$ & $\checkmark$ & $\checkmark$ \\
\hline & 3 & $\begin{array}{l}\text { HQ management by } \\
\text { exception }\end{array}$ & $\checkmark$ & $\checkmark$ & & & \\
\hline & 4 & $\begin{array}{l}\text { Transparency of } \\
\text { information flow } \\
\text { (between } \mathrm{HQ} \text { and } \\
\text { subsidiary) }\end{array}$ & & & & & $\checkmark$ \\
\hline \multirow{8}{*}{ Standardisation } & 5 & Boundaries delineated & & & & $\checkmark$ & \\
\hline & 6 & $\begin{array}{l}\text { Codification of actions } \\
\text { (rules \& instructions) }\end{array}$ & & & $\checkmark$ & & \\
\hline & 7 & Standardised systems & & & $\checkmark$ & & \\
\hline & 8 & $\begin{array}{l}\text { Codification of targets } \\
\text { (internally determined) }\end{array}$ & & $\checkmark$ & & & \\
\hline & 9 & Flexibility of targets & & $\checkmark$ (reversed) & & & $\sqrt{ }$ \\
\hline & 10 & $\begin{array}{l}\text { Broad HQ performance } \\
\text { expectations }\end{array}$ & & & & & $\checkmark$ \\
\hline & 11 & $\begin{array}{l}\text { Emergent HQ } \\
\text { performance expectations }\end{array}$ & & & & & $\checkmark$ \\
\hline & 12 & Set limits on activities & & & & $\checkmark$ & \\
\hline \multirow{6}{*}{$\begin{array}{c}\text { Monitoring \& performance } \\
\text { evaluation }\end{array}$} & 13 & $\begin{array}{l}\text { Adherence to codified } \\
\text { actions (policies and } \\
\text { procedures) monitored }\end{array}$ & & & $\checkmark$ & & \\
\hline & 14 & $\begin{array}{l}\text { Monitoring \& evaluation } \\
\text { based on codified targets }\end{array}$ & & $\checkmark$ & & & \\
\hline & 15 & $\begin{array}{l}\text { Monitoring \& evaluation } \\
\text { according to market } \\
\text { benchmarks }\end{array}$ & $\checkmark$ & & & & \\
\hline & 16 & $\begin{array}{l}\text { Long term performance } \\
\text { assessment }\end{array}$ & & & & & $\checkmark$ \\
\hline & 17 & $\begin{array}{l}\text { Subjectivity in } \\
\text { performance evaluation }\end{array}$ & & & & & $\checkmark$ \\
\hline & 18 & $\begin{array}{l}\text { HQ periodically checking } \\
\text { compliance with } \\
\text { boundaries }\end{array}$ & & & & $\checkmark$ & \\
\hline \multirow{6}{*}{ Rewards } & 19 & $\begin{array}{l}\text { Punishment for not } \\
\text { complying with codified } \\
\text { actions }\end{array}$ & & & $\checkmark$ & & \\
\hline & 20 & $\begin{array}{l}\text { Rewards based on } \\
\text { codified evaluation }\end{array}$ & & $\checkmark$ & & & \\
\hline & 21 & $\begin{array}{l}\text { Rewards tied to market } \\
\text { based performance } \\
\text { evaluation }\end{array}$ & $\checkmark$ & & & & \\
\hline & 22 & $\begin{array}{l}\text { Reward through } \\
\text { promotion }\end{array}$ & & & & & $\checkmark$ \\
\hline & 23 & $\begin{array}{l}\text { Subjectivity in reward } \\
\text { determination }\end{array}$ & & & & & $\checkmark$ \\
\hline & 24 & $\begin{array}{l}\text { Severe sanctions for } \\
\text { crossing boundaries }\end{array}$ & & & & $\checkmark$ & \\
\hline
\end{tabular}


Table 3 - Factor analysis of control archetypes

\begin{tabular}{lcc}
\hline $\begin{array}{l}\text { Constructs } \\
\text { Indicators }\end{array}$ & $\begin{array}{c}\text { Rotated Factor } \\
\text { Loading }\end{array}$ & $\begin{array}{c}\text { PCA } \\
\text { Communality }\end{array}$ \\
\hline $\begin{array}{l}\text { Arm's length control } \\
\text { Monitoring \& evaluation according to market benchmarks } \\
\text { (MCI15) }\end{array}$ & 0.923 & 0.852 \\
$\begin{array}{l}\text { Rewards tied to market based performance evaluation (MCI21) } \\
\text { Results oriented machine control }\end{array}$ & 0.923 & 0.852 \\
Codifications of targets (MCI8) & & 0.586 \\
Monitoring \& evaluation based on codified targets (MCI14) & 0.766 & 0.779 \\
Rewards based on codified evaluation (MCI20) & 0.883 & 0.717 \\
$\begin{array}{l}\text { Action oriented machine control } \\
\text { Codification of actions (MCI6) }\end{array}$ & 0.847 & 0.602 \\
Adherence to codified actions (MCI13) & & 0.714 \\
Punishment for not complying with codified actions (MCI19) & 0.776 & 0.570 \\
Boundary control & 0.845 & 0.755 \\
Boundaries delineated (MCI 5) & & 0.650 \\
HQ periodically checking compliance with boundaries (MCI 18) & & 0.590 \\
Severe sanctions for crossing boundaries (MCI 24) & 0.806 & 0.591 \\
Exploratory control \\
Transparency of information flow (MCI 4) \\
Flexibility of targets (MCI 9)
\end{tabular}

Table 4 - Control archetype composite reliability

\begin{tabular}{lc}
\hline Construct & Cronbach's Alpha \\
\hline Arm's length control & 0.826 \\
Results oriented machine control & 0.775 \\
Action oriented machine control & 0.701 \\
Boundary control & 0.678 \\
Exploratory control & 0.584 \\
\hline
\end{tabular}

Table 5 - Square root of AVE and control archetype correlations

\begin{tabular}{lccccc}
\hline & $\begin{array}{c}\text { Arm's length } \\
\text { control }\end{array}$ & $\begin{array}{c}\text { Results oriented } \\
\text { machine control }\end{array}$ & $\begin{array}{c}\text { Action oriented } \\
\text { machine control }\end{array}$ & $\begin{array}{c}\text { Boundary } \\
\text { control }\end{array}$ & $\begin{array}{c}\text { Exploratory } \\
\text { control }\end{array}$ \\
\hline $\begin{array}{l}\text { Arm's length control } \\
\text { Results oriented }\end{array}$ & $\mathbf{0 . 9 2 3}$ & & & & \\
machine control & 0.426 & $\mathbf{0 . 8 3 3}$ & & & \\
$\begin{array}{l}\text { Action oriented } \\
\text { machine control }\end{array}$ & 0.327 & 0.402 & $\mathbf{0 . 7 9 3}$ & & \\
$\begin{array}{l}\text { Boundary control } \\
\text { Exploratory control }\end{array}$ & 0.315 & 0.374 & 0.816 & $\mathbf{0 . 7 8 1}$ & $\mathbf{0 . 6 6 8}$ \\
\hline
\end{tabular}


Table 6 - OLS regression based on modified version of Speklé (2001)

\begin{tabular}{|c|c|c|c|c|c|c|c|c|c|c|c|}
\hline \multirow[t]{2}{*}{ Equation } & \multirow[t]{2}{*}{$\begin{array}{l}\text { Control } \\
\text { archetype }\end{array}$} & \multicolumn{6}{|c|}{$\begin{array}{c}\text { Ex post hoc } \\
\text { information } \\
\text { impactedness }\end{array}$} & \multicolumn{2}{|c|}{ Size } & \multirow[b]{2}{*}{ Adjusted $R^{2}$} & \multirow[b]{2}{*}{$F$-stat ( $p$-value) } \\
\hline & & Coeff. & $t$-stat & Coeff. & $t$-stat & Coeff. & $t$-stat & Coeff. & $t$-stat & & \\
\hline 1 & Arm's length & -0.414 & $-1.786^{*}$ & -0.052 & -0.653 & $\mathrm{n} / \mathrm{a}$ & & 0.124 & 1.566 & 0.018 & $(0.120)$ \\
\hline 2 & Results & -0.042 & -0.550 & -0.046 & -0.595 & -0.029 & -0.378 & 0.313 & $4.041^{* * *}$ & 0.078 & $4.321^{* * *}(0.002)$ \\
\hline 3 & Action & -0.249 & $-3.442 * * *$ & -0.141 & $-1.957^{*}$ & -0.294 & $-4.036 * * *$ & 0.204 & $2.809 * * *$ & 0.187 & $10.098^{* * *}(0.000)$ \\
\hline 4 & Boundary & -0.302 & $-4.164 * * *$ & $\mathrm{n} / \mathrm{a}$ & & -0.280 & $-3.824 * * *$ & 0.158 & $2.168^{* *}$ & 0.181 & $12.623^{* * *}(0.000)$ \\
\hline 5 & Exploratory & -0.246 & $-3.205^{* * *}$ & $\mathrm{n} / \mathrm{a}$ & & -0.175 & $-2.262^{* *}$ & 0.071 & 0.921 & 0.083 & $5.778 * * *(0.001)$ \\
\hline
\end{tabular}

